\title{
« Manichaean Sogdian and Uighur letters recently unearthed in Bezeklik, Turfan ». Studies on the Inner Asian languages 15 (2000), pp. 135-178 [in Japanese].
}

\section{Nicholas Sims-Williams}

\section{(2) OpenEdition}

\section{Journals}

Édition électronique

URL : http://journals.openedition.org/abstractairanica/35158

DOI : 10.4000/abstractairanica.35158

ISSN : 1961-960X

Éditeur :

CNRS (UMR 7528 Mondes iraniens et indiens), Éditions de l'IFRI

\section{Édition imprimée}

Date de publication : 15 mai 2002

ISSN : 0240-8910

Référence électronique

Nicholas Sims-Williams, « "Manichaean Sogdian and Uighur letters recently unearthed in Bezeklik, Turfan ». Studies on the Inner Asian languages 15 (2000), pp. 135-178 [in Japanese]. », Abstracta Iranica [En ligne], Volume 23 | 2002, document 30, mis en ligne le 08 février 2010, consulté le 25 septembre 2020. URL : http://journals.openedition.org/abstractairanica/35158 ; DOI : https://doi.org/10.4000/ abstractairanica.35158

Ce document a été généré automatiquement le 25 septembre 2020.

Tous droits réservés 
« Manichaean Sogdian and Uighur letters recently unearthed in Bezeklik, Turfan ». Studies on the Inner Asian languages 15 (2000), pp. 135-178 [in Japanese].

Nicholas Sims-Williams

Partial Japanese version of $n^{\circ} 22$, including Yoshida's edition and translation of the three Sogdian letters A-C (without commentary, glossary or plates) and Moriyasu's edition and translation of the Uighur letters D-H.

\section{INDEX}

Thèmes : 2.1. Langues anciennes

\section{AUTEURS}

NICHOLAS SIMS-WILLIAMS

Université de Londres - Grande-Bretagne 